\title{
LABOR \\ RELATIONS \\ IN A \\ GLOBALIZING WORLD
}



Harry C. Katz,

Thomas A. Kochan, and

Alexander J. S. Colvin

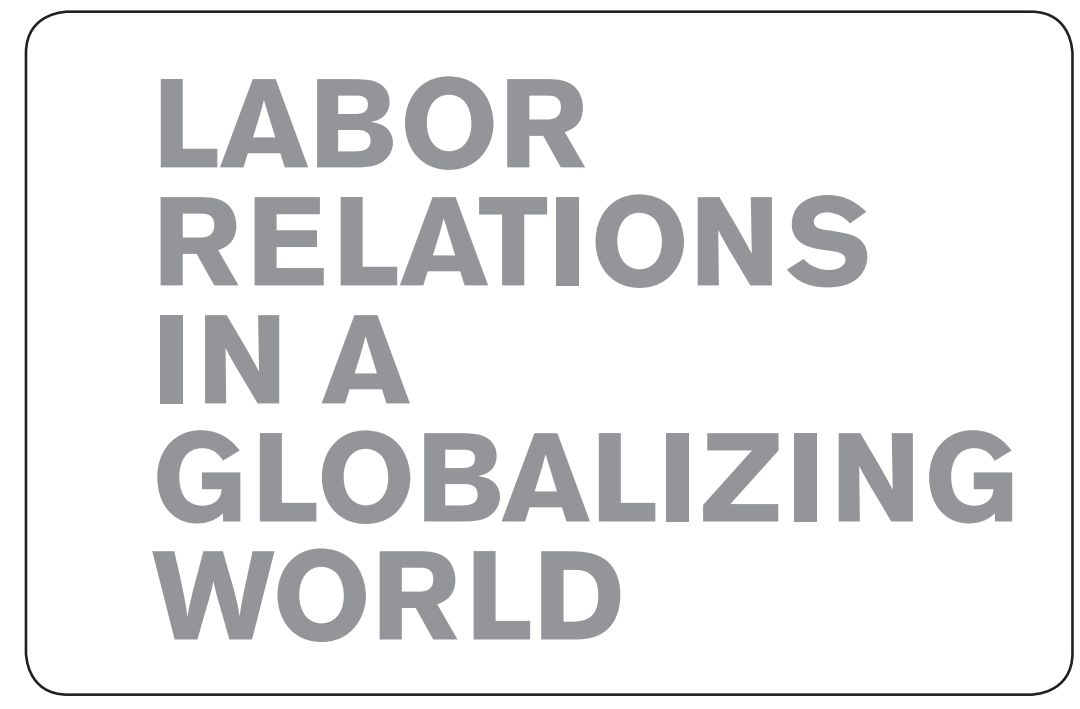

ILR Press

an imprint of

Cornell University Press

Ithaca and London 


\section{Copyright (C) 2015 by Cornell University}

All rights reserved. Except for brief quotations in a review, this book, or parts thereof, must not be reproduced in any form without permission in writing from the publisher. For information, address Cornell University Press, Sage House, 512 East State Street, Ithaca, New York 14850 .

First published 2015 by Cornell University Press

First printing, Cornell Paperbacks, 2015

Printed in the United States of America

Library of Congress Cataloging-in-Publication Data

Katz, Harry Charles, 1951- author.

Labor relations in a globalizing world / Harry C. Katz, Thomas A. Kochan, and Alexander J.S. Colvin. pages $\mathrm{cm}$

Includes bibliographical references and index.

ISBN 978-0-8014-5381-6 (cloth : alk. paper)

ISBN 978-0-8014-7989-2 (pbk. : alk. paper)

1. Industrial relations-Developing countries. 2. Comparative industrial relations. 3. Labor and globalization. I. Kochan, Thomas A., author. II. Colvin, Alexander James, author. III. Title.

HD8943.K38 2015

$331.09172^{\prime} 4-\mathrm{dc} 23$

\section{1}

Cornell University Press strives to use environmentally responsible suppliers and materials to the fullest extent possible in the publishing of its books. Such materials include vegetable-based, low-VOC inks and acid-free papers that are recycled, totally chlorine-free, or partly composed of nonwood fibers. For further information, visit our website at www.cornellpress.cornell.edu.

Cloth printing $\quad 10987654321$

Paperback printing $\quad \begin{array}{llllllllll}10 & 9 & 8 & 7 & 6 & 5 & 4 & 3 & 2 & 1\end{array}$ 
To our many teachers 
